\title{
In situ patch closure of ventricular septal defect with aortic regurgitation
}

\author{
Fuat Buyukbayrak, Eray Aksoy, Serpil Gezer Tas, Mehmet Dedemoglu, Mete Alp \\ Kartal Kosuyolu Education and Research Hospital, Department of Cardiovascular Surgery, Istanbul, Turkey \\ Kardiochirurgia i Torakochirurgia Polska 2013; 10 (1): 31-33
}

\begin{abstract}
Aortic valve prolapse (AVP) in patients with a ventricular septal defect (VSD) is known to be caused by high gradient flow through the defect. In adult patients, VSD may lead to AVP and subsequent aortic regurgitation (AR). Although aortic valvuloplasty and the concurrent closure of the defect is the therapy of choice for children, it carries a high risk of reoperation in adults. We present a case of a 20-year-old male with perimembranous outlet type VSD and severe AR. During the operation, the non-coronary cusp was inverted towards the defect and used as an in situ patch. The severely deformed coronary cusps were excised and the aortic valve was replaced. Key words: ventricular septal defect, aortic regurgitation.
\end{abstract}

Aortic regurgitation (AR) may accompany ventricular septal defects (VSD) in advanced stages. Several mechanisms have been suggested for the development of aortic valve prolapse in patients with ventricular septal defects. The Venturi effect is the predominant cause, resulting in aortic cusps being drawn into the high velocity and low pressure zone created by left to right shunt. This model also explains the cause of the progressive nature of this valvular deformity, which is actually absent at birth. Patients suffering from mild aortic valve prolapse with small restrictive ventricular septal defects may be followed up with routine examination during childhood. Progression to mild to moderate AR necessitates surgical intervention even in normally growing children without heart failure symptoms. Later in childhood (between 5 and 10 years of age), the ongoing shunt of blood across the ventricles causes further prolapse of the affected cusps and prevents their apposition during diastole, resulting in moderate to severe AR [1, 2].

Aortic valvuloplasty and the concomitant closure of the defect achieve satisfactory long-term results in childhood. However, in older patients with structural deformity

\section{Streszczenie}

Wypadanie płatka zastawki aortalnej u chorych z ubytkiem w przegrodzie międzykomorowej jest czynnikiem powodującym powstanie wysokiego gradientu przez ubytek. U chorych dorosłych VSD może prowadzić do AVP i w konsekwencji do niedomykalności aortalnej (aortic regurgitation - AR). Chociaż walwuloplastyka zastawki aortalnej z jednoczesnym zamknięciem ubytku jest metodą leczenia z wyboru u dzieci, to wiąże się ona z wysokim ryzykiem reoperacji u dorosłych. W pracy przedstawiono przypadek 20-letniego mężczyzny z okołobłoniastym typem VSD i ciężką AR. Podczas zabiegu do zaszycia ubytku wykorzystano płatek niewieńcowy. Uszkodzone płatki zastawki wycięto, zastępując je zastawką aortalną.

Słowa kluczowe: ubytek w przegrodzie międzykomorowej, niedomykalność aortalna.

and advanced leaflet retraction, aortic valve replacement may be necessary.

\section{Case report}

A 20-year-old male presented with persistent fatigue and dyspnea. He gave a history of heart murmur, which was diagnosed when he was three years old. Echocardiography revealed a perimembranous outlet type VSD with a diameter of $10 \mathrm{~mm}$. Additionally, it was found that the right coronary cusp was prolapsing into the left ventricular outflow tract, which caused severe aortic regurgitation. Mean pulmonary artery pressure was $35 \mathrm{mmHg}$, indicating mild pulmonary hypertension.

During the operation, cardiopulmonary bypass was established in a standardized fashion. Transverse aortotomy was performed approximately $1 \mathrm{~cm}$ above the aortic valve. The initial assessment revealed that the right coronary cusp was thickened and prolapsing through the aortic root. The left coronary cusp was retracted towards the annulus. Commissural fusion was present between the right coronary and the non-coronary cusps. The wall of the non-cor- 
onary sinus of Valsalva was thin and weakened. The noncoronary aortic leaflet was healthy. Since the left and right aortic cusps were severely deformed and the risk of failure was deemed too high, a valve repair procedure was not considered. The coronary leaflets were resected and the ventricular septal defect was easily reached through aortotomy. It was a perimembranous outlet type defect of approximately $10 \mathrm{~mm}$ in diameter. Free margins of the noncoronary cusp were tailored to the size of the defect. The leaflet was inverted downwards and sutured to the defect in a continuous fashion using 5.0 polypropylene suture material and a No. 21 St. Jude mechanical prosthetic valve was implanted supra-annularly. The patient was weaned from cardiopulmonary bypass with minimal inotropic support. The cross clamp and cardiopulmonary bypass times were 58 minutes and 73 minutes, respectively. The postoperative course was uneventful. The patient was discharged on the fifth postoperative day; a six-month follow-up echocardiography showed no residual shunt.

\section{Discussion}

In this report, we present our experience with a patient who was diagnosed with AR and VSD. During the operation, the non-coronary cusp was slightly enlarged and, when inverted, this pliable and healthy cusp was could easily be tailored to the margins of the ventricular septal defect. The aortic wall was markedly weakened and did not seem to carry overlapping stitches when both the mechanic valve and pericardium patch were sutured, which was the main reason why we used the non-coronary cusp as a patch. Since autologous pericardial patches are prone to aneurysm formation after closure of large VSDs and

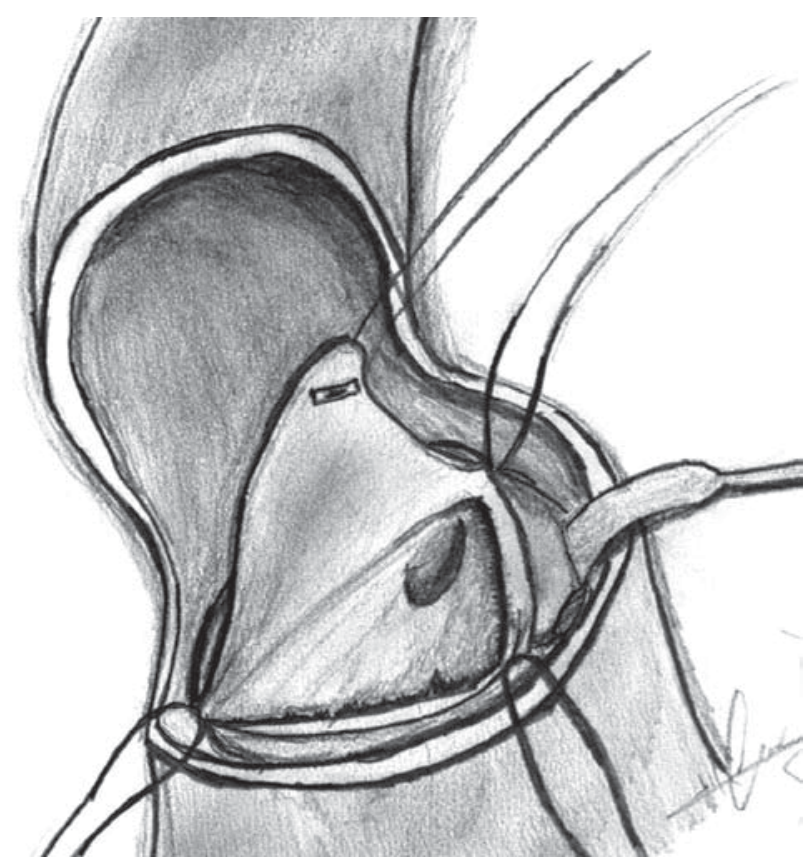

Fig. 1. Ventricular septal defect seen beneath the aortic annulus. Non-coronary cusp retracted the use of Dacron patches involves the risk of infective endocarditis, we avoided using either of these materials in the patient who underwent concomitant mechanical valve replacement $[3,4]$.

Aortic valve prolapse may be associated with outlet type ventricular septal defects. Moreover, in patients with juxtaarterial defects, the incidence was approximately two times higher when compared to other defect types [1]. According to previous studies, the incidence of AVP associated with ventricular septal defects was between $7.5 \%$ and $52.7 \%$. AR was found in $4.8 \%$ to $14 \%$ of patients with AVP $[1,5]$.

The Venturi effect is assumed to be responsible for the cusp prolapse found in restrictive ventricular septal defects. It is the predominant cause of aortic valve cusp deformity and the subsequent AR. This is true for all subtypes of ventricular septal defects. Since this pathology has a progressive nature, the determination of more than trivial AR should alert the physician, and, in such cases, surgery should not be delayed. Although the indication is less clear, we believe that the presence of AVP in a patient with a ventricular septal defect deserves surgical intervention because of the progressive nature of the lesion.

Aortic valvuloplasty has satisfactory results in patients without structural leaflet degeneration. However, it is controversial to repair a structurally abnormal aortic valve. Moreover, the presence of associated abnormalities as well as the age of the patient at the time of the operation may also affect the outcomes of aortic repair. Rao et al. suggested that the presence of ventricular septal defects at the time of valve repair significantly increased the risk of

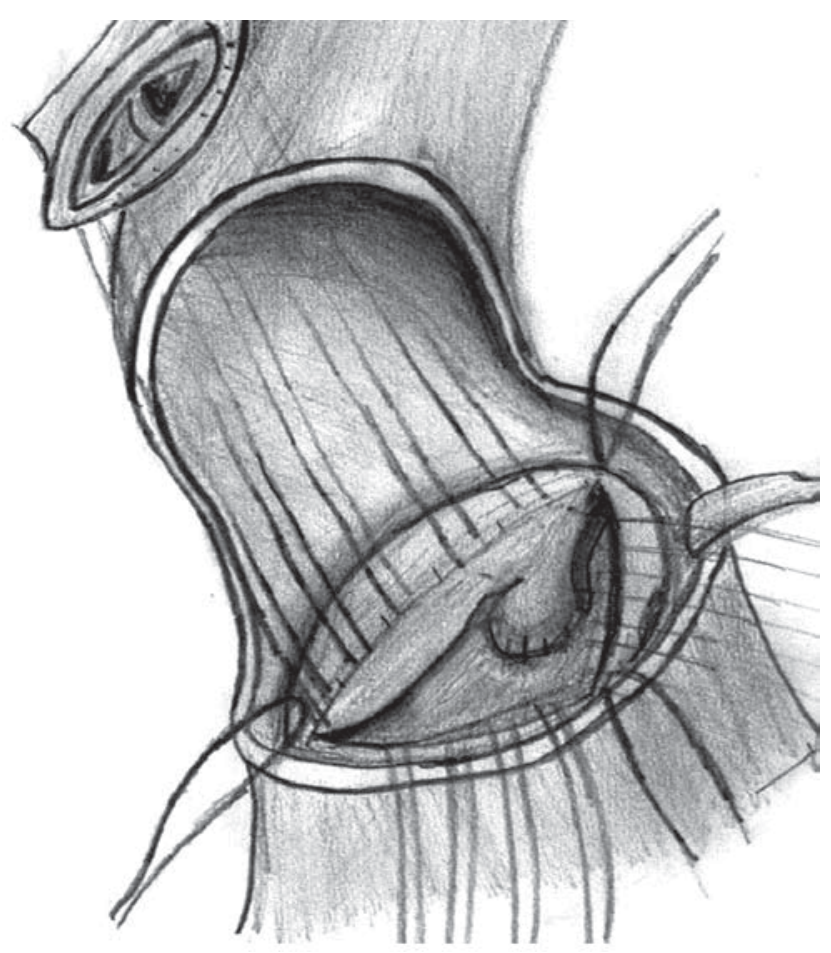

Fig. 2. Ventricular septal defect closed and mechanical valve stitches passed 
the procedure, whereas bicuspid valve, subaortic stenosis, and mitral valve surgery did not affect the outcome. In his study, $56 \%$ of patients required reoperation or experienced recurrent aortic insufficiency at a mean follow-up of 5 years [6]. Older age at operation may be another factor affecting the success of valve repair in patients with ventricular septal defect. Rathore et al. proposed that valve repair in children gives satisfactory results, whereas valve replacement is a better option for older patients, because the presence of structural changes, including the loss of pliability and advanced prolapse, makes the valve repair more prone to failure [7]. In a series reported by Chiu et al., among 400 patients with AR and ventricular septal defects, it was found that only age ( $>15$ years) and the severity of AR were significant predictors of aortic valve replacement [8]. Finally, Trusler et al. concluded in their late results that the presence of associated structural defects was predictive for repair failure, whereas age at repair and the type of ventricular septal defects were not significant risk factors [9].

The literature includes a few examples of using a valve leaflet in order to repair another deformed valve structure. A non-coronary cusp has already been used in a successful reconstruction of the right ventricular outflow tract [10]. In conclusion, the use of aortic valve leaflets for VSD closure in select cases can be an acceptable technique and may provide satisfactory outcomes.

\section{References}

1. Chiu SN, Wang JK, Lin MT, Wu ET, Lu FL, Chang Cl, Chen YS, Chiu IS, Lue HC, $\mathrm{Wu} \mathrm{MH}$. Aortic valve prolapse associated with outlet-type ventricular septal defect. Ann Thorac Surg 2005; 79: 1366-1371.

2. Tweddell JS, Pelech AN, Frommelt PC. Ventricular septal defect and aortic valve regurgitation: pathophysiology and indications for surgery. Semin Thorac Cardiovasc Surg Pediatr Card Surg Annu 2006: 147-52.

3. Bennink GB, Hitchcock FJ, Molenschot M, Hutter P, Sreeram N. Aneurysmal pericardial patch producing right ventricular inflow obstruction. Ann Thorac Surg 2001; 71: 1346-1347.

4. Vaideeswar P, Mishra P, Nimbalkar M. Infective endocarditis of the Dacron patch-a report of 13 cases at autopsy. Cardiovasc Pathol 2011; 20: 169-175.

5. Eroğlu AG, Oztunç F, Saltik L, Dedeoğlu S, Bakari S, Ahunbay G. Aortic valve prolapse and aortic regurgitation in patients with ventricular septal defect. Pediatr Cardiol 2003; 24: 36-39.

6. Rao V, Van Arsdell GS, David TE, Azakie A, Williams WG. Aortic valve repair for adult congenital heart disease: a twenty-two year experience. Circulation 2000; 102 (19 Suppl 2): III40-III43.

7. Rathore KS. Aortic regurgitation with ventricular septal defect in the young. Asian Cardiovasc Thorac Ann. 2006; 14:93-97

8. Chiu SN, Wang JK, Lin MT, Chen CA, Chen HC, Chang Cl, Chen YS, Chiu IS, Lue HC, Wu MH. Progression of aortic regurgitation after surgical repair of outlet-type ventricular septal defects. Am Heart J 2007; 153: 336-342.

9. Trusler GA, Williams WG, Smallhorn JF, Freedom RM. Late results after repair of aortic insufficiency associated with ventricular septal defect. J Thorac Cardiovasc Surg 1992; 103: 276-281.

10. Yamagishi M, Emmoto T, Wada Y, Oka T. Pulmonary reconstruction in the ross procedure: combined autologous aortic and polytetrafluoroethylene valve. J Thorac Cardiovasc Surg 1998; 116: 1076-1077. 